\title{
Assessment of the Influence of Various Agro-Technological Methods on the Development of Diseases, Pests, as Well as on the Lodging of Spring Wheat of the Ulyanovskaya 105 Variety in the Conditions of Predkamye of the Republic of Tatarstan
}

\author{
Farit Shaikhutdinov, Igor Serzhanov*, Razil Garayev and Albina Serzhanova \\ Kazan State Agrarian University, 65, K. Marx str., Kazan, 420015, Republic of Tatarstan, Russia
}

\begin{abstract}
The article is devoted to the question of the influence of various agro-technological methods on the development of diseases, pests, as well as on the lodging of spring wheat. Over the years of research (2019-2020) on spring wheat crops, the effect of calculated doses of fertilizers at different rates of sowing seeds on plant damage by latent pests and leaf rust damage, as well as the resistance of spring wheat plants to lodging was studied. On the basis of the results obtained, it was possible to establish that at strongly reduced seeding rates, regardless of the nutritional background, the number of damaged plants by the fruit fly, as well as damage by leaf rust, increased sharply. At the same time, excessive thickening of crops did not contribute to a significant further decrease in damage and susceptibility, as well as to lodging of plants.
\end{abstract}

\section{Introduction}

The sown area of spring wheat in the Predkamye zone of the Republic of Tatarstan occupies more than 100 thousand hectares. Increasing the productivity of the main food crop remains the most important task of farmers in this zone [1-3].

A significant role in the reduction of grain yield is played by disease incidence and damage to plants by stem pests [4-6].

Numerous experimental studies carried out on the reasons for the lodging of spring spike crops made it possible to establish their diversity: this is an incorrect one-sided nitrogen nutrition, in case of violation of the optimal plant density per unit area, as a result of which the light regime deteriorates, etc. Under such conditions, a very weak root system develops, the stems stretch out and become less durable, which leads to lodging of plants $[7 ; 8]$

The loss of yield due to lodging cannot be associated only with physical losses, since its decline starts with a violation of the processes of assimilation and the outflow of assimilants into the grain. In this regard, it can be assumed that the nature of qualitative changes can vary widely depending on the period in which the lodging occurred $[9 ; 10]$.

\section{Research methods}

The spring soft wheat variety Ulyanovskaya 105, included in the state register for the seventh region, was used as an object of research. Experimental studies, the results of which are presented in this article, were carried out over two years 2019-2020. The agrochemical parameters of the soils of the experimental plots were as follows: humus content (according to I.V. Tyurin) was 3.2-3.4\%, $\mathrm{P}_{2} \mathrm{O}_{5}$ content (according to Kirsanov) was $198-250 \mathrm{mg} / \mathrm{kg}, \mathrm{K}_{2} \mathrm{O}$ content was $138-140 \mathrm{mg} / \mathrm{kg}$ of soil, saline $\mathrm{pH}$ was $5.8-6.1$.

The experiments were carried out in the developed, typical for the zone, field crop rotation. Wheat was usually sown after winter rye. For experiments related to the application of fertilizers by the calculation and balance method to the next level of yield, fertilizers, as a background for pre-sowing cultivation, $\mathrm{N}_{63-68} \mathrm{P}_{45-49} \mathrm{~K}_{30}$ 32 was introduced as average background, $\mathrm{N}_{89-96} \mathrm{P}_{71-77}$ $\mathrm{K}_{57-63}$ as elevated background. The control variant in terms of nutritional background was a natural background (without fertilizers). Four seeding rates were tested against each nutritional background (4, 5, 6 and 7 million seeds per hectare). Experiments were carried out, as a rule, in four repetitions. The size of the plots in the experiments was $36 \mathrm{~m}^{2}$. Sowing was carried out in the first days of field work in the region (May 4 and 5). For sowing, first-class seeds were used in accordance with GOST. Agricultural technology was generally accepted for the Republic of Tatarstan. The harvesting of the experimental plots was carried out with a SAMPO-500 combine.

\section{Results and discussion}

In 2019-2020, agrometeorological conditions were favorable for the growth and development of the studied culture (Fig. 1).

\footnotetext{
* Corresponding author: igor.serzhanov@mail.ru
} 
Meteorological conditions during the years of experiments with the object of research differed both in the amount of precipitation during the growing season and in the thermal regime. These meteorological elements favored the growth and development of spring wheat: in 2019, GTC amounted to 1.36 units, in 2020,
GTK amounted to 1.13 units, which made it possible to establish the reaction of the studied spring wheat variety on the action of factors which were involved in the research (Fig. 1).

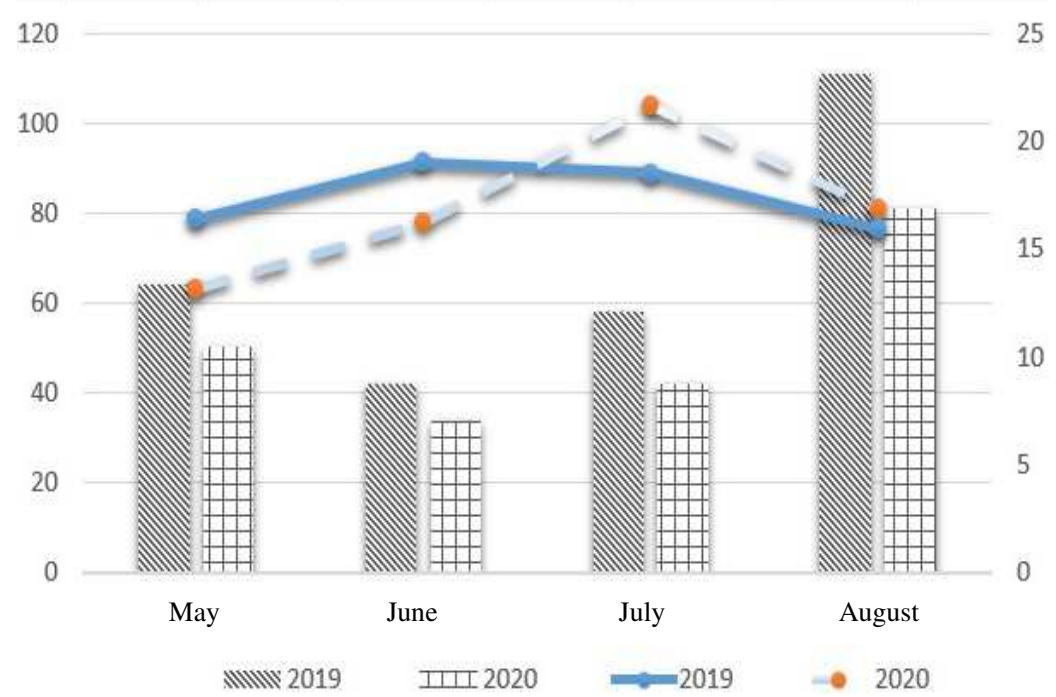

Fig. 1. Meteorological conditions during the growing season of spring wheat (according to the agrometeopost "Kabany" of Laishevsky district of the Republic of Tatarstan)

Table 1. Field germination and safety of spring wheat plants of the Ulyanovskaya 105 variety at different seeding rates and nutritional backgrounds, on average for 2019-2020

\begin{tabular}{|c|c|c|c|c|c|c|}
\hline \multirow[b]{2}{*}{ Nutrition backgrounds } & \multirow[b]{2}{*}{$\begin{array}{c}\text { Seeding rate [million } \\
\text { seeds/ha] }\end{array}$} & \multicolumn{2}{|c|}{ Full shoots } & \multicolumn{3}{|c|}{ Preservation of plants to full ripeness } \\
\hline & & $\begin{array}{c}\text { number of } \\
\text { plants } \\
{\left[\mathrm{pcs} . / \mathbf{m}^{2}\right]}\end{array}$ & $\begin{array}{c}\text { field } \\
\text { germinati } \\
\text { on }[\%]\end{array}$ & $\begin{array}{c}\text { number of plants } \\
{\left[\mathrm{pcs} . / \mathbf{m}^{2}\right]}\end{array}$ & $\begin{array}{c}\% \text { of } \\
\text { seedling } \\
\mathrm{s}\end{array}$ & $\begin{array}{c}\% \text { of sown } \\
\text { seeds }\end{array}$ \\
\hline \multirow{4}{*}{ I } & 4 & 324 & 79.5 & 292 & 90.1 & 73.0 \\
\hline & 5 & 379 & 75.8 & 349 & 92.0 & 69.8 \\
\hline & 6 & 441 & 73.5 & 410 & 92.9 & 68.3 \\
\hline & 7 & 513 & 69.6 & 473 & 92.2 & 67.5 \\
\hline \multirow{4}{*}{ II } & 4 & 319 & 79.0 & 295 & 92.4 & 73.8 \\
\hline & 5 & 275 & 75.0 & 356 & 94.9 & 71.2 \\
\hline & 6 & 439 & 73.1 & 422 & 96.0 & 70.3 \\
\hline & 7 & 507 & 69.3 & 478 & 94.3 & 68.3 \\
\hline \multirow{4}{*}{ III } & 4 & 319 & 80.5 & 295 & 92.4 & 73.8 \\
\hline & 5 & 375 & 75.0 & 356 & 94.9 & 71.2 \\
\hline & 6 & 439 & 73.1 & 422 & 96.0 & 70.3 \\
\hline & 7 & 507 & 69.1 & 478 & 94.3 & 68.3 \\
\hline
\end{tabular}

The plant density of spring wheat directly depended on the sowing rate of seeds (Table 1).

The results of our research showed that, on average, for 2 years on all nutrition backgrounds, a change in the seeding rate of spring wheat had an effect on field germination. With an increase in the seeding rate from 4 to 7 million, field germination decreased regardless of the nutrition background. The influence of the nutritional background on the seedling emergence process was not observed, however, the safety of plants on fertilized variants was better than on the natural background. The underestimated seeding rates (4 million units per hectare), regardless of the nutritional level, ensured the highest field germination rate (79.0-80.5\%). As the seeding rate increased at all nutrition levels, the field germination rate varied within 79.5-69.6 \%
(I background), 79.0-69.3\% (II background) and 80.5-69.1\% (III background). With an increase in the seeding rate, the survival rate of plants also decreased. Apparently, this is due to a deterioration in the light regime, moisture supply of plants, as well as damage by stem pests and damage by leaf rust. The density of the productive stalk in our experiments was also conditioned by the degree of tillering of plants (Table 2).

Table 2 shows that an increase in the seeding rate from 4 to 7 million reduced the total and productive bushiness. In particular, the productive tillering of the Ulyanovskaya 105 variety on background I (control) decreased from 1.08 to 1.00 , on background II-III, from 1.13 to 1.00. Observations have shown that the colonization of crops by stem pests depends on the density of plants (Table 3). 
Table 2. Bushiness at different seeding rates and nutrition backgrounds on average for 2019-2020

\begin{tabular}{|c|c|c|c|c|c|c|}
\hline \multirow{2}{*}{$\begin{array}{c}\text { Seeding rates } \\
\text { [million seeds/ha] }\end{array}$} & \multicolumn{2}{|c|}{ I background } & \multicolumn{2}{c|}{ II background } & \multicolumn{2}{c|}{ III background } \\
\cline { 2 - 7 } & Total & Productive & Total & Productive & Total & Productive \\
\hline 4 & 1.30 & 1.08 & 1.35 & 1.13 & 1.37 & 1.13 \\
5 & 1.18 & 1.06 & 1.23 & 1.06 & 1.21 & 1.10 \\
6 & 1.10 & 1.00 & 1.15 & 1.00 & 1.13 & 1.03 \\
7 & 1.05 & 1.00 & 1.03 & 1.00 & 1.07 & 1.00 \\
\hline
\end{tabular}

Table 3. Influence of planting density under different nutritional backgrounds on the damageability by the fruit fly

\begin{tabular}{|c|c|c|c|c|c|c|c|c|c|c|}
\hline \multirow[b]{2}{*}{ 氙 } & \multirow[b]{2}{*}{ 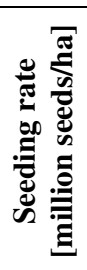 } & \multicolumn{3}{|c|}{2019} & \multicolumn{3}{|c|}{2020} & \multicolumn{3}{|c|}{ Average } \\
\hline & & 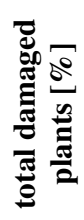 & 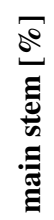 & 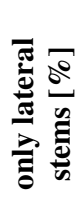 & 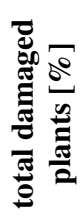 & 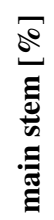 & 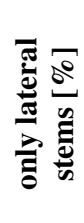 & 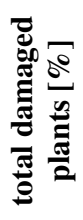 & 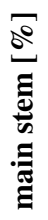 & 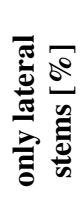 \\
\hline Natural (control) & $\begin{array}{l}4 \\
5 \\
6 \\
7\end{array}$ & $\begin{array}{c}25 \\
18 \\
7 \\
3\end{array}$ & $\begin{array}{l}5 \\
3 \\
1 \\
1\end{array}$ & $\begin{array}{c}18 \\
13 \\
5 \\
3\end{array}$ & $\begin{array}{l}30 \\
25 \\
22 \\
14\end{array}$ & $\begin{array}{l}2 \\
2 \\
0 \\
0\end{array}$ & $\begin{array}{l}26 \\
22 \\
20 \\
15\end{array}$ & $\begin{array}{l}29 \\
23 \\
18 \\
12\end{array}$ & $\begin{array}{l}5 \\
4 \\
2 \\
1\end{array}$ & $\begin{array}{l}24 \\
19 \\
16 \\
11\end{array}$ \\
\hline $\begin{array}{c}\text { Average norm } \\
\text { (NPK per } 3 \text { tons of } \\
\text { grain from ha) }\end{array}$ & $\begin{array}{l}4 \\
5 \\
6 \\
7\end{array}$ & $\begin{array}{c}32 \\
21 \\
12 \\
5\end{array}$ & $\begin{array}{l}5 \\
2 \\
2 \\
0\end{array}$ & $\begin{array}{c}26 \\
17 \\
8 \\
3\end{array}$ & $\begin{array}{l}34 \\
28 \\
25 \\
19\end{array}$ & $\begin{array}{l}4 \\
3 \\
2 \\
1\end{array}$ & $\begin{array}{l}29 \\
25 \\
23 \\
17\end{array}$ & $\begin{array}{l}36 \\
28 \\
23 \\
14\end{array}$ & $\begin{array}{l}6 \\
4 \\
3 \\
2\end{array}$ & $\begin{array}{l}30 \\
24 \\
20 \\
12\end{array}$ \\
\hline $\begin{array}{l}\text { Increased norm } \\
\text { (NPK per } 4 \text { tons of } \\
\text { grain from ha) }\end{array}$ & $\begin{array}{l}4 \\
5 \\
6 \\
7\end{array}$ & $\begin{array}{c}36 \\
27 \\
15 \\
7\end{array}$ & $\begin{array}{l}6 \\
4 \\
4 \\
2 \\
\end{array}$ & $\begin{array}{c}24 \\
17 \\
11 \\
5\end{array}$ & $\begin{array}{l}37 \\
31 \\
26 \\
22\end{array}$ & $\begin{array}{l}5 \\
3 \\
3 \\
1\end{array}$ & $\begin{array}{l}31 \\
27 \\
22 \\
21\end{array}$ & $\begin{array}{l}36 \\
29 \\
21 \\
15\end{array}$ & $\begin{array}{l}7 \\
5 \\
4 \\
2\end{array}$ & $\begin{array}{l}29 \\
24 \\
17 \\
13\end{array}$ \\
\hline
\end{tabular}

Based on the analysis of the experimental data in Table 2, the differences in the damageability of spring wheat plants by the fruit fly were revealed depending on the seeding rates and the nutritional background. On all nutritional backgrounds, with strongly underestimated seeding rates (4 million), the number of damaged plants increased sharply, but mainly due to damage to the secondary lateral stems.
Among the reasons that have a negative impact on the productivity of spring wheat, a special place is occupied by plant disease. During the years of research, spring wheat plants were mainly affected by leaf rust, which was determined in the phase of milk ripeness of grain, according to the scale number 1 .

Observations showed that the background of nutrition and the density of the stalk influenced the incidence of diseases (Table 4).

Table 4. Influence of certain technological methods of cultivation on the degree of damage by leaf rust

\begin{tabular}{|c|c|c|c|c|}
\hline \multirow{2}{*}{ Fertilizer } & Seeding rate [million & \multicolumn{3}{|c|}{ Degree of damage by leaf rust [\%] } \\
\cline { 3 - 5 } & seeds/ha] & $\mathbf{2 0 1 9}$ & $\mathbf{2 0 2 0}$ & 7.8 \\
\hline Natural (control) & 4 & 7.4 & 8.2 & 8.6 \\
& 5 & 8.0 & 11.6 & 11.4 \\
& 6 & 10.5 & 21.4 & 6.6 \\
\hline Average norm & 7 & 19.7 & 7.0 & 7.3 \\
& 4 & 6.1 & 7.8 & 8.2 \\
(NPK per 3 tons of grain & 5 & 7.3 & 8.6 & 18.5 \\
from ha) & 6 & 7.0 & 6.5 & 6.1 \\
& 7 & 5.1 & 8.4 & 7.9 \\
\end{tabular}

Experimental data indicate that the resistance of wheat plants to leaf rust. In these variants, the degree of damage decreased by 3.0-3.5\% compared to the natural background. The seeding rate was 6 million hectares. Apparently, the improved nutritional regime of the soil contributed to the strengthening of the physiological state of plants, including resistance to pathogens.
Regardless of the nutritional level with a thickened stalk per unit area, the infestation of plants increased due to a decrease in the area of plant nutrition. In such an environment, as a rule, the growth and development of plants weaken, the temperature and humidity conditions change sharply, which creates favorable conditions for pathogens.

During the years of research, in order to establish the resistance of spring wheat cultivar Ulyanovskaya 105, 
lodging of plants was determined on various experimental options.

This definition was carried out twice: in the phase of milk ripeness of grain and immediately before harvesting.

In both years of research, an increase in lodging of plants was observed under the influence of applied doses of mineral fertilizers, especially on thickened crops with a seeding rate of 7 million viable seeds per hectare (Table 5).
According to Table 5, during the years of research on fertilized variants of the experiment, the resistance to field-logging of plants before harvesting significantly decreased in comparison with the control. However, the assessment of resistance was not lower than average (3 points). At optimal seeding rates, 5 million on the control and 6 million on fertilized backgrounds, the score did not fall below 4.6-5.0 points on the control, and below 3.5-4.0 and 3.4-3.7 when applying calculated doses of fertilizers.

Table 5. Degree of plant lodging depending on the area and nutrition background

\begin{tabular}{|c|c|c|c|c|c|}
\hline \multirow{2}{*}{$\begin{array}{c}\text { Nutrition } \\
\text { background }\end{array}$} & \multirow{2}{*}{$\begin{array}{c}\text { Seeding rate } \\
\text { [million seeds/ha] }\end{array}$} & \multicolumn{4}{|c|}{ Lodging degree [points] } \\
\cline { 3 - 6 } & & \multicolumn{2}{|c|}{$\mathbf{2 0 1 9}$} & \multicolumn{2}{|c|}{$\mathbf{2 0 2 0}$} \\
\cline { 3 - 6 } & & Milk ripeness & Before harvest & Milk ripeness & Before harvest \\
\hline No fertilizers & 4 & 5.0 & 5.0 & 4.6 & 4.6 \\
(control) & 5 & 5.0 & 5.0 & 4.6 & 4.6 \\
& 6 & 5.0 & 5.0 & 4.0 & 3.0 \\
\hline Average norm & 7 & 4.9 & 4.5 & 4.1 & 3.7 \\
(NPK per 3 tons of & 4 & 4.8 & 4.8 & 4.1 & 3.7 \\
grain from ha) & 5 & 4.4 & 3.1 & 3.7 & 3.4 \\
& 6 & 4.1 & 3.7 & 3.5 & 3.4 \\
\hline Increased norm & 4 & 4.9 & 4.4 & 3.9 & 3.5 \\
(NPK per 4 tons of & 5 & 4.2 & 4.0 & 3.8 & 3.4 \\
grain from ha) & 6 & 4.0 & 3.7 & 3.5 & 3.4 \\
& 7 & 3.7 & 3.5 & 3.3 & 3.1 \\
\hline
\end{tabular}

Observations have shown that the degree of lodging of spring wheat crops depends not only on the background and area of plant nutrition, but also on weather conditions during the growing season. For instance, the humid summer of 2020 and especially the heavy rains at the end of the grain filling caused a significant lodging of crops.

Lodging could not but affect the movement of substances from vegetative organs to generative ones, assimilation and metabolism, and also promoted onesided illumination of the stem, as a result of which ripening was delayed and puny, underdeveloped seeds were formed, which leads to a decrease in the mass of 1000 grains. A decrease in the mass of 1000 seeds due to a violation of the grain filling process is one of the main reasons for a decrease in yield when lodging crops. At the same time, the earlier it happened, the more harvest is lost.

Based on the research carried out on the experimental fields of the Kazan State Agrarian University, Shaikhutdinov, Serzhanov, Amirov et al. [7] conclude that the main economic damage from lodging of spring wheat is not the deterioration of the technological properties of grain, but a sharp decline in yield.

Thus, summing up, it can be noted that lodging manifests itself more significantly where the soil fertility and the dose of mineral nutrition are higher, and along with physical losses of grain during harvesting, there is a shortage of harvest due to disruption of the grain filling processes, especially in the case when lodging occurred in phase of milk ripeness of grain. Along with the quantitative losses in the yield, there are significant changes in quality indicators.

\section{Conclusion}

Less damage to spring wheat plants by the fruit fly and damage by leaf rust is observed at the optimal seeding rate on all nutrition backgrounds.

During the years of research, it was established that the Ulyanovskaya 105 spring wheat variety has a higher average resistance to lodging.

\section{References}

1. M.F. Amirov, I.M. Serzhanov, F.Sh. Shaikhutdinov, M.Yu. Gilyazov, H.Z. Karimov, IOP Conf. Ser. Earth Envir. Sci., 341, 012025 (2019)

2. I.D. Davlyatshin, L.G. Gaffarova, IOP Conf. Ser. Earth and Envir. Sci., 272 (2019)

3. R.I. Safin, L.Z. Karimova, S.Z. Validov, Biotech.: state of the art and persp. (2018)

4. R. Sabirov, A. Valiev, L. Karimova, A. Dmitriev, D. Khaliullin, Engin. for rural devel. Proc. (2019)

5. F.N. Safiollin, R.M. Nizamov, M.V. Panasyuk, S.R. Suleymanov, A.A. Akhmetzyanov, BIO Web of Conf., 17, 00241 (2020)

6. F.N. Safiollin, S.R. Suleymanov, S.V. Sochneva, N.V. Trofimov, I.G. Malganova, BIO Web of Conf. 17, 00062 (2020)

7. F.Sh. Shaikhutdinov, I.M. Serzhanov, M.F. Amirov, A.R. Valiev, R.M. Nizamov, IOP Conf. Ser. Earth and Envir. Sci., 341 (2019) 
8. A.M. Sabirzyanov, N.A. Loginov, I.P. Talanov, M.V. Panasyuk, T.G. Hadeyev, IOP Conf. Ser. Earth and Envir. Sci, 341 (2019)
9. M.Yu. Gilyazov, Eurasi. Soil Sci. (2002)

10. V.I. Kostin, F.A. Mudarisov, A.I. Krivova, Bull. of the Russ. Acad. of Natural Sci. (2014) 